\title{
The concepts of planning and design in sustainable stormwater management
}

\author{
I. Tukiman, I. Zen \& M. F. Musa \\ Department of Landscape Architecture, \\ International Islamic University Malaysia, Malaysia
}

\begin{abstract}
Stormwater management requires general ideas and principles known as the "concept" to ensure the success of planning and design. In addition, the concept requires an understanding of the hydrology cycle as a basis of knowledge, which provides a mechanism to synthesize the knowledge of the hydrology cycle with the idea of planning and designing for stormwater management. Thus, this research aims to synthesize the concepts of stormwater management with that of the hydrology cycle as the environmental sustainability factor. Two objectives have been established: (i) to identify the concepts of planning and designing of stormwater management; and (ii) to analyse the relationship of the identified concepts with the hydrology cycle. In this qualitative research, three methods of data collection have been used: online journals, forum discussions and e-mail interviews. The collected data were analysed using five steps of descriptive comparative analysis. The results show eleven concepts: conservation of the watershed, compact urban form, retention of stormwater on site, treatment train, green network, harvesting and reuse of rainwater, redevelopment, streetscape ecosystem and restoration. The concepts are listed according to seven hydrology cycles - interception, infiltration, surface runoff, depression storage, evapotranspiration, groundwater flow and interflow. The hydrology cycle becomes the environmental sustainability factor for the identified concepts, as the goal of stormwater management is to replicate the process of the hydrology cycle to ensure the effectiveness of the concepts.
\end{abstract}

Keywords: stormwater management, concepts, principles, planning, design, sustainable, hydrology cycle, environment. 


\section{Introduction}

Stormwater is an excessive quantity of surface runoff. Stormwater happens during precipitation due to a decrement in the interception and infiltration rate of rainfall and due to an increment in the volume and flow rate of surface runoff. Consequently, a high and rapid volume of stormwater is discharged into rivers (low-lying area) in a short period of intense precipitation that causes overflowing and flooding of the nearby area (Chia Chong Wing [1]; Hassan [2]; Marsh [3]; Day and Dickinson [4]). In addition to flood issues, stormwater also causes river pollution and soil erosion, which damages the environmental habitat and public property (Department of Environment Malaysia [5]).

This severe environmental and social-economic damage happens because of major and abrupt alterations to the hydrology cycle. The pervious cover of nature is changed and deteriorates dramatically into a massive impervious cover of development. Vegetation cover is cleared and the landform is flattened and developed into buildings, roads, parking lots and pavements. The receiving water body, especially rivers, are changed - straightened, widened and structured into storm drainage (Marsh [3]; Day and Dickinson [4]; Department of Irrigation and Drainage Malaysia [6]; Miguez et al. [7]).

Specifically, according to Marsh [3], the runoff coefficient in urban areas can increase dramatically up to 90 to 100 per cent compared to the runoff coefficient in natural areas, which range from 10 to 20 per cent. The increase in the runoff coefficient is due to the loss of vegetation cover, soil composition and texture and landform slope, which function by controlling the infiltration and surface runoff of the hydrology cycle. The attributes of urban ecosystems with less vegetation cover to intercept the rainfall, less green areas, together with an increase in impaired soil texture and altered landform make it less permeable for the rainwater to infiltrate into the ground.

There are many stormwater management approaches to overcome the issues caused by stormwater, which cover stormwater quantity and quality aspects. Stormwater management is either a conventional conveyance approach like a storm drain or sustainable stormwater management, which focuses on a naturebased approach, such as Sustainable Urban Drainage Systems (SUDS), LowImpact Development (LID) and Water Sensitive Urban Design (WSUD). All of the stormwater management manuals provide a wide range of guidelines, such as planning, design and technical construction.

This research intends to discuss the planning and design part of stormwater management. Specifically, the aim of this research is to synthesize the concepts of planning and design of stormwater management with the hydrology cycle as the environmental sustainability factor. Two objectives were established: (i) to identify the concepts of planning and design of stormwater management; and (ii) to analyse the relationship of the identified concepts with the hydrology cycle. 


\section{Concept of planning and design}

The planning and design of the landscape is about connecting and synthesizing the knowledge of landscape ecosystems and design solutions for sustainable development and management. Lyle [8], in his definition on landscape design, emphasized the need to have scientific knowledge of natural ecosystems. In addition, Steiner [9] defined ecological planning as the use of biophysical and socio-cultural information to propose opportunities and constraints for decisionmaking in landscape development. Likewise, McHarg [10] described ecological planning as the understanding of biophysical and social processes in an ecosystem through the operation of laws and time. Furthermore, Lyle [8] proposed that the scientific knowledge of ecosystem design can be categorized into two. First, is knowledge of the landscape. It is important before planning and designing a landscape to know the biological process within the landscape. Second is the concept of design. In landscape design, the concept is crucial because it provides access to the mechanisms that join all the knowledge of the landscape ecosystem. The concept of planning and design offers a clear basis as an accepted reference according to which it appraises a means to manage a complex relation within a landscape (Kaplan [11]). Therefore, a concept of planning and design can be considered as a general idea or principle of solution for sustainable development and management.

Consequently, to identify the concept of planning and design for stormwater management, a hydrology cycle, together with its biophysical elements and processes, needs to be studied. This is crucial to ensure that the identified concept will contribute to the sustainability factor of planning and design of stormwater management that can replicate the natural hydrology cycle that has been lost due to improper planning and design.

\section{Hydrology cycle as the environmental sustainability factor}

Marsh [3] mentioned that in the hydrology cycle, the processes of the hydrology cycle are interrelated with other biophysical elements, such as topography, soils, vegetation and water bodies. In a natural landscape, the hydrology cycle is a continuous process of various forms of inflow and outflow of the hydrology cycle within the biophysical elements of a landscape (Ferguson [12]; Steiner [9]). It signifies the order of the movement of water in the landscape by diverse phases and forms. Table 1 shows the summary of the hydrology cycle, interrelated biophysical elements and the processes within a landscape. The scientific knowledge studied from this review was used as a sustainability factor for the identified concepts. Consequently, the hydrology cycle together with the biophysical elements and the processes were used as the basic concept for the planning and design of sustainable stormwater management in this research. 
Table 1: Hydrology cycle, interrelated biophysical elements and the process (Marsh [3]; Steiner [9]; Ferguson [12]).

\begin{tabular}{|c|c|c|}
\hline Hydrology Cycle & Biophysical Element Involved & Process \\
\hline 1. Interception & $\begin{array}{l}\text { 1. Vegetation } \\
\text { (strata of trees, shrubs \& } \\
\text { groundcovers) }\end{array}$ & $\begin{array}{l}\text { Interception and } \\
\text { evapotranspiration. }\end{array}$ \\
\hline 2. Infiltration & $\begin{array}{l}\text { 1. Surface of landscape: } \\
\text { 1.1. Soil (types, permeability } \\
\text { and saturation) } \\
\text { 1.2. Vegetation }\end{array}$ & $\begin{array}{l}\text { Infiltration and absorption } \\
\text { through permeability of soil } \\
\text { and by root systems of } \\
\text { vegetation. }\end{array}$ \\
\hline 3. Surface runoff & $\begin{array}{l}\text { 1. Topography and slope } \\
\text { 2. Surface roughness: } \\
\text { 2.1. Vegetation } \\
\text { 2.2. Soil type } \\
\text { 3. Water bodies } \\
\text { (pond, lake, wetland and river) }\end{array}$ & $\begin{array}{l}\text { Surface runoff flow into the } \\
\text { lower area. }\end{array}$ \\
\hline $\begin{array}{l}\text { 4. Depression } \\
\text { storage }\end{array}$ & $\begin{array}{l}\text { 1. Topography } \\
\text { (landscape depression) } \\
\text { 2. Water bodies } \\
\text { (pond, lake, wetland and river) }\end{array}$ & $\begin{array}{l}\text { Collected within micro- } \\
\text { topography and water } \\
\text { bodies. }\end{array}$ \\
\hline $\begin{array}{l}\text { 5. Evapo- } \\
\text { transpiration }\end{array}$ & $\begin{array}{l}\text { 1. Vegetation } \\
\text { 2. Water bodies } \\
\text { (pond, lake, wetland and river) }\end{array}$ & $\begin{array}{l}\text { Evapo-transpiration: } \\
\text { retention of water and slow } \\
\text { evaporation into the air. }\end{array}$ \\
\hline $\begin{array}{l}\text { 6. Groundwater } \\
\text { flow }\end{array}$ & $\begin{array}{l}\text { 1. Soil (types, permeability and } \\
\text { saturation) }\end{array}$ & $\begin{array}{l}\text { Infiltration and absorption. } \\
\text { Slow discharge into streams } \\
\text { through aquifer storage } \\
\text { layer in the ground. }\end{array}$ \\
\hline 7. Interflow & $\begin{array}{l}\text { 1. Soil (types, permeability and } \\
\text { saturation) }\end{array}$ & $\begin{array}{l}\text { Infiltration and absorption. } \\
\text { Slow discharge into streams } \\
\text { through vadose storage } \\
\text { layer in the ground. }\end{array}$ \\
\hline
\end{tabular}

\section{Methodology}

In this research, the qualitative approach was used as it is considered to be the best suited to the aim and objectives of the research. Three research methods were used. Firstly, 35 topics from the online journal at http://www.stormh2o.com that are related to the concept of planning and design of stormwater management were studied from the January 2007 to May 2012 issues. Secondly, a topic about the concept of planning and design of stormwater management was posted to a Google group forum discussion (http:/groups.google.com/group/rainwater-incontext) through which four respondents replied and gave eight attached links to documents. In addition, twenty related topics in the forum discussion were 
studied. Lastly, eight respondents answered the e-mail interview in which thirteen more documents were attached to the e-mail for reference. Furthermore, grounded theory was used as a strategy of inquiry to seek interaction among the collected data and to derive an understanding about the identified concepts (Charmaz [13]; Glaser and Strauss [14]; Creswell [15]). In analysing the collected data, five sequential steps of descriptive comparative analysis were used (Creswell [15]) (Figure 1).
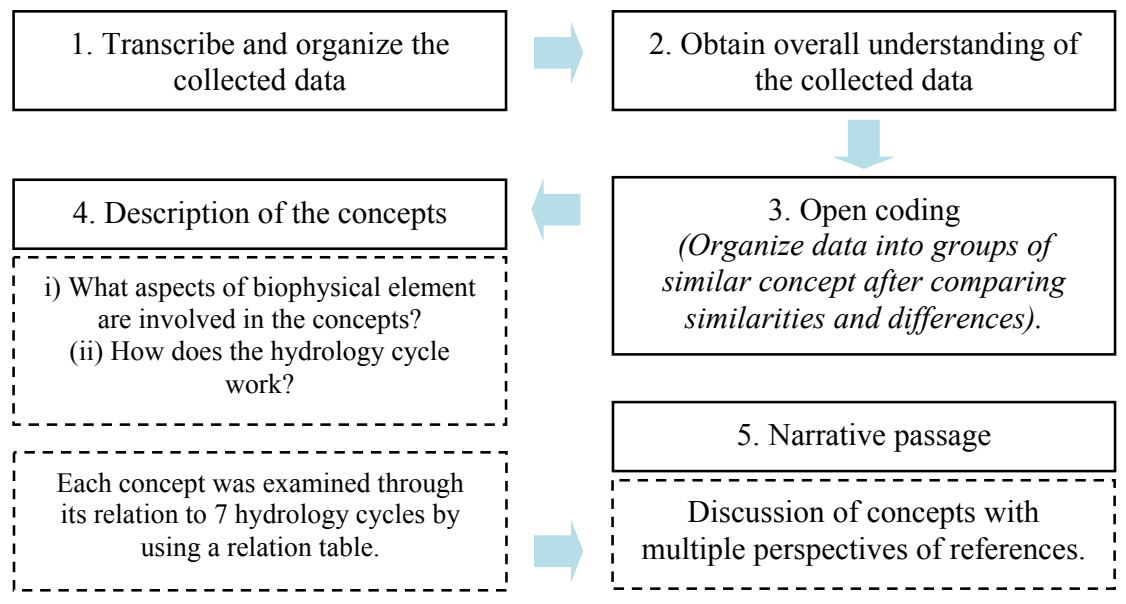

Figure 1: Five steps of descriptive comparative analysis (Creswell [15]).

\section{Result and discussion}

Eleven concepts of planning and design have been identified after the analysis process.

The first concept is the conservation of the watershed. The conservation of the watershed is considered as a main priority concept of planning and design by the Toronto and Region Conservation Authority [17]. The conservation of the watershed covers the conservation and protection of crucial water body ecosystems or hydrologic elements, such as stream buffers and wetlands to act as natural stormwater quality and quantity management. The conservation of the watershed relates to all hydrology cycles: interception, infiltration, surface runoff, depression storage, evapotranspiration, interflow and groundwater flow. The undisturbed biophysical elements of vegetation, topography, water bodies and soil can function at optimum level to filter the stormwater from nearby development, as mentioned by Richards [16].

The second concept is the harvesting and reuse of rainwater. Crabtree [18], Hager [19] and the Australian and New Zealand Environment and Conservation Council [20] stated that rainwater needs to be harvested and reused as a multipurpose resource. The harvesting and reuse of rainwater concept relates to six hydrology cycles: interception, infiltration, surface runoff, depression storage, evapo-transpiration and groundwater flow. The interception refers to collecting 
the rainwater from roofs and gutters, and channeling the rainwater into a rain barrel for later reuse. The infiltration, surface runoff, depression storage, evapotranspiration and groundwater flow refer to the reuse of harvested rainwater for watering the landscape or plants, especially during the dry season. The reuse of rainwater promotes inexpensive and sustainable significant water reuse when practiced by the community in long-term planning.

The third concept is the compact urban form. The compact urban form combines three planning and design ideas: (i) preservation of the natural environment, (ii) planning of the compact form or layout of a city, and (iii) planning for the high density of population and infrastructure (Aurbach [21]). The sustainability of the compact urban form can be achieved by planning a mixed-use development of commercial, institutional and residential, and a mixed-transit network (Nisenson [23]). Similarly, it can be achieved by designing multi-use green infrastructures or strategies, as highlighted by Dumont [22]. The idea behind a compact urban form is to restrict the development to a concentrated area within a watershed boundary in order to protect more pristine watershed areas. The compact urban form relates to all hydrology cycles: interception, infiltration, surface runoff, depression storage, evapotranspiration, interflow and groundwater flow. Through the compact urban form, the conserved watershed area can function at optimum level to manage the stormwater issue, as mentioned in the first concept. The conserved biophysical elements can filter and clean the stormwater and wastewater from nearby high density and compact areas.

The fourth concept is redevelopment. Redevelopment, also known as retrofit or infill development, is a concept to achieve compact urban form and high density. Stormwater management in the redevelopment concept focuses on multifunctional stormwater infrastructures or strategies within developed areas, as mentioned by EPA-NOAA Smart Growth Implementation Assistance for Coastal Communities for Sussex County, Delaware [24] and Ferguson [25]. Multifunctional refers to various benefits offered by a single stormwater infrastructure. For example, a wetland strategy offers various benefits to the wildlife ecosystem and also a recreational area for the community. The redevelopment concept relates to six hydrology cycles: interception, infiltration, surface runoff, depression storage, evapo-transpiration and groundwater flow. The interflow cycle is not related to redevelopment, because, according to Stephens and Dumont [26], interflow cannot function without a vadose storage layer of soil. In developed areas, the vadose storage layer is usually removed due to construction works, such as the insertion of underground pipes and digging of drainage. Moreover, Stephens and Dumont [26] stressed that once the vadose storage layer has been lost, its restoration is impossible. Since the redevelopment concept focuses on developed areas, it can only restore the interception, infiltration, surface runoff, depression storage, evapo-transpiration and groundwater flow cycles.

The fifth concept is retention of stormwater on site. Retaining on site means storing the retained stormwater and releasing the stormwater slowly over a period of time. The release process of the stormwater is to return the stormwater 
into the ground to recharge the underground water table; for instance, the use of the storage basin strategy (Marsh [3]). In addition, Hager [19] and the Construction Industry Research and Information Association (CIRIA) [27] indicated the design of subsurface storage, such as basins, ponds and a rain garden strategy to promote storage and infiltration of stormwater for better management. Moreover, the Australian and New Zealand Environment and Conservation Council [20] specified two levels of treatment to retain stormwater on site. The secondary level of treatment requires the use of strategies like filter strips, grass swale, extended detention (dry) basins, infiltration trenches and infiltration basins for the sedimentation and filtration process. The third level of treatment requires the use of pond and wetland strategies for the sedimentation, filtration and adsorption process. The retention of stormwater on site relates to seven hydrology cycles: interception, infiltration, surface runoff, depression storage, evapotranspiration, groundwater flow and interflow. According to Briglio [28] and Ferguson [29], the depression storage cycle happens when the stormwater is collected at the lowest depression of landform, while the evapotranspiration cycle happens through vegetation and water body ecosystems. The infiltration and groundwater flow cycle function through the root system of vegetation and soil (Ferguson [29]; Rutherford [30]; Low [31]). In addition, researchers have suggested that interception and surface runoff cycles also occur in stormwater retention on site. This is because of the use of vegetation as part of the biophysical elements in the concept: the foliage of vegetation will intercept some of the rainwater before the stormwater flows into the retention area. The surface runoff cycle occurs during the process of directing the stormwater into the retention area. Furthermore, researchers classified the interflow cycle based on two conditions: in natural landscapes and in developed landscapes (Briglio [28]). In natural landscapes, the interflow cycle can function as the vadose storage layer of soil is still conserved. Unlike in developed landscapes where the interflow cycle cannot function due to the absence of a vadose storage layer of soil (refer to Stephens and Dumont [26], as explained in the fourth concept).

The sixth concept is the treatment train. The treatment train is a modification of the train or landform to manage stormwater in the lowest areas and to protect the buildings and infrastructure by locating them in the highest areas. According to Low [31], the "treatment train is a method of integrating several strategies for various functions such as paving, channeling, storage and filtration that collectively manage the stormwater". The treatment train concept can be classified into two areas: (i) upper-stream or highest point of the site, and (ii) downstream or lowest point of the site, as suggested by Broughton [32]. The classification is important in order to plan and design the strategies at site-scale level. In the upper-stream areas, source control strategies are crucial to reduce and treat the stormwater quantity and quality to reduce the impact in the downstream areas (Marsh [3]; Toronto and Region Conservation [17]; Broughton [32]). The treatment train relates to seven hydrology cycles: interception, infiltration, surface runoff, depression storage, evapotranspiration, interflow and groundwater flow, as it combines collective strategies (Low [31]). The infiltration, interflow and groundwater flow cycles function through the root 
system of vegetation and soil. The surface runoff and depression storage cycles function through the movement of stormwater from the highest point of upperstream into the lowest point of downstream. Lastly, the interception and evapotranspiration cycles function through vegetation and water body ecosystems. Furthermore, for the interflow cycle, researchers have classified it based on two situations: (i) natural landscape, and (ii) developed landscape (refer to Stephens and Dumont [26] and Briglio [28], as explained in the fourth and fifth concepts).

The seventh concept is the streetscape ecosystem. The streetscape ecosystem involves the integration of stormwater strategies with the street and its features, such as the median and traffic circles. Strategies like street planting and vegetative swale help to reduce the impervious cover (Toronto and Region Conservation [17]; Hager [19]; Australian and New Zealand Environment and Conservation Council [20]). Through the streetscape ecosystem, one of the extensive impervious covers can be used as a medium to manage stormwater. This is a good opportunity as the street is the main source of stormwater, and, to manage stormwater at the source, is very important. The stormwater from the street should be diverted from the drainage and directed into the landscaped curb, median and traffic circles where the vegetation can remediate the stormwater through the phytoremediation process. The streetscape ecosystem relates to six hydrology cycles: interception, infiltration, surface runoff, depression storage, evapo-transpiration and groundwater flow. The interception and evapotranspiration cycles happen through vegetation planted along the street and at the landscaped street features. The surface runoff and depression storage cycles happen by directing and storing the stormwater into the landscaped curb, median and traffic circles. The infiltration and groundwater flow cycles occur at the landscaped street features through the root system of vegetation and soil while the interflow cycle cannot take place because the streetscape is within a developed area (refer to Stephens and Dumont [26], as explained in the fourth concept).

The eight concept is restoration. Restoration concerns rehabilitating to a former condition: from a degraded condition to a healthy condition of biophysical elements of topography and slope, vegetation, soil and water bodies for the hydrology cycle to function. Marsh [3] and Hager [19] emphasized the strategy of soil, vegetation and topography restoration in order to restore the conveyance, storage, infiltration and treatment processes of the hydrology cycle. According to the Australian and New Zealand Environment and Conservation Council [20] and the Construction Industry Research and Information Association (CIRIA) [27], the conveyance process can be restored through filter strips and swale. The storage process can be restored through basins and ponds, while infiltration and treatment can be achieved through permeable and filter drains. Restoration relates to six hydrology cycles: interception, infiltration, surface runoff, depression storage, evapo-transpiration and groundwater flow. The interception and evapotranspiration cycles occur through restoration of the vegetation and water body ecosystems. The surface runoff and depression storage cycles occur through restoration of the topography and slope, and water 
body ecosystems. Lastly, the infiltration and groundwater flow cycles occur through the root system of the vegetation and soil.

The last concept is the green network which is about the conservation and restoration of interconnected natural areas and retrofit green areas, especially the hydrology ecosystems. The green network is important in large-scale watershed planning to ensure the stormwater can be managed at the optimum level through all the processes of the hydrology cycle within the biophysical elements of the green network. The green network relates to all the hydrology cycles: interception, infiltration, surface runoff, depression storage, evapo-transpiration, interflow and groundwater flow. All the hydrology cycles can function because of the conservation of critical ecological areas, such as wetlands, riparian corridors and flood plains where all the biophysical elements are intact for optimum biological functions.

Lastly, the identified concepts are listed in relation to the order of priority (Table 2). The order of priority is based on the order of the highest relation of each concept with the hydrology cycle. In Table 2, the concept for number three

Table 2: Relationship of hydrology cycles with the concepts of planning and design of stormwater management.

\begin{tabular}{|l|l|l|l|l|l|l|}
\hline Concept & & & & \\
\end{tabular}


is similar to number eight, and concept number four is similar to number nine. However, the concept has certain differences in the "presence of natural or undisturbed natural water body ecosystems" (green colour code) and "without the presence of natural or undisturbed natural water body ecosystems" (yellow colour code). The difference in the coding is significant enough to give a novel insight into the classification of the concepts. The reason being that the green colour code highlighted the significance to conserve the pristine biophysical elements for the hydrology cycle to function at the optimum level, whereas the yellow colour code showed the deficiency in the interflow cycle.

\section{Conclusion}

In conclusion, to achieve sustainable stormwater management, a clear fundamental concept of planning and design must be outlined. The concept must be based on scientific knowledge in order to ensure the success of planning and design. In the context of stormwater management, the concept was outlined based on the hydrology cycle, the biophysical elements and the processes in order to replicate the hydrology cycle within landscape development. The researchers note that the priority order list of the concepts is important to identify which concept should be focused on, and to give a clear classification and information for the decision-making in respect of planning and design in sustainable stormwater management.

\section{Acknowledgement}

The authors acknowledge the fund received from the Ministry of Education Malaysia under the Exploratory Research Grant Scheme (ERGS).

\section{References}

[1] Chia Chong Wing, Managing flood problems in Malaysia. Buletin Ingenieur 22, pp. 38-43, 2004.

[2] Ahmad Sanusi Hassan, Reka Bentuk Bandar Di Semenanjung Malaysia Kuala Lumpur Dan Bandar Baru Di Sekitarnya, Penerbit Universiti Sains Malaysia: Pulau Pinang, Malaysia, 2005.

[3] Marsh, W. M., Landscape Planning Environmental Applications, John Wiley \& Sons, Inc.: United States of America, 2005.

[4] Day, S. D. \& Dickinson, S. B., (eds). Managing Stormwater for Urban Sustainability using Trees and Structural Soils, Virginia Polytechnic Institute and State University: Blacksburg, Virginia, 2008.

[5] Department of Environment Malaysia, Malaysia Environmental Quality Report 2006. Sasyaz Holdings Sdn. Bhd.: Petaling Jaya, Malaysia, 2007. 
[6] Department of Irrigation and Drainage Malaysia, Flash Flood Management. (Television Programme), RTM: Kuala Lumpur, (nd).

[7] Miguez, M.G., Mascarenhas, F.C.B. \& Magalhaes, L.P.C., Multifunctional landscapes for urban flood control in developing countries. International Journal of Sustainable Development Planning, (2(2), pp. 153-166, 2007.

[8] Lyle, J. T., Design for Human Ecosystems, Island Press: Washington, DC, 1999.

[9] Steiner, F., The Living Landscape, Island Press: Washington, DC, 2008.

[10] McHarg, I. L., Design with Nature, John Wiley \& Sons, Inc: United States of America, 1992.

[11] Kaplan, A., Landscape architecture's commitment to landscape concept: a missing link? Journal of Landscape Architecture, 4(1), pp. 56-65, 2012.

[12] Ferguson, B. K., Introduction to Stormwater. John Wiley \& Sons, Inc: United States of America, 1998.

[13] Charmaz, K., The grounded theory method: an explication and interpretation. More Grounded Theory Methodology: A Reader, ed. Sociology Press: United States of America, pp. 95-115, 1994.

[14] Glaser, B. G. \& Strauss, A. L., The Discovery of Grounded Theory: Strategies for Qualitative Research, Aldine de Gruyter: United States of America, 1999.

[15] Creswell, J. W., Research Design, Sage Publications: United States of America, 2003.

[16] Richards, L. (2011). Stormwater Management at a Transportation Plan Level, http:/groups.google.com/group/rainwaterincontext/browse_thread/ thread/7808d32c9e2a5c80?hl=en\#http://groups.google.com/group/ rainwaterincontext/browse thread/thread/7808d32c9e2a5c80?hl=en\#

[17] Toronto and Region Conservation for the Living City, Low Impact Development Stormwater Management Planning and Design Guide, Canada Government Printing Office: Ontario, Canada, 2010.

[18] Crabtree, P. (2011). Cage Match: Walkable Urban Environments vs. Low ImpactDesign, http://groups.google.com/group/rainwaterincontext/ Walkable+Urban+Environments+vs.+Low+Impact+Design\#http://groups. google.com/group/rainwaterincontext/Walkable+Urban+Environments + vs. + Low + Impact+Design\#

[19] Hager, M. C. (2003). Low Impact Development, http://www.stormh2o.com

[20] Australian and New Zealand Environment and Conservation Council, Australian Guidelines for Urban Stormwater Management, Australia Government Printing Office: Australia, 2000.

[21] Aurbach, L. (2010). Dense and Beautiful Stormwater Management, http://pedshed.net/?p=270

[22] Dumont, J. (2011). Street Storage of Stormwater, http:/groups.google.com/group/rainwaterincontext/Street + storage + of + stor mwater\#992f4b1dcd5295fc

[23] Nisenson, L. (2011). Cage Match: Walkable Urban Environments vs. LowImpactDesign,http://groups.google.com/group/rainwaterincontext/ 
Cage+Match $\% 3 \mathrm{~A}+$ Walkable+Urban+Environments + vs. + Low + Impact + Design\#

[24] EPA-NOAA Smart Growth Implementation Assistance for Coastal Communities for Sussex County, Delaware, Protecting Water Quality with Smart Growth Strategies and Natural Stormwater Management in Sussex County, Delaware, Sussex County, Delaware: United States of America, 2009.

[25] Ferguson, B. K, Restorative urban design. Water Resources Impact, 6(5), pp. 9-12, 2004.

[26] Stephens, K. A. \& Dumont, J. (2011). Rainwater Management in a Watershed Context, http://www.stormh2o.com

[27] Construction Industry Research and Information Association, Sustainable Urban Drainage Systems, Cromwell Press: Great Britain, 2001.

[28] Briglio, D. (2011). Practicality, Feasibility, and Compliance in Stormwater Management, http://www.stormh2o.com

[29] Ferguson, B. K., Stormwater management and stormwater restoration. Handbook of Water Sensitive Planning and Design, ed. CRC Press: New York, 2002.

[30] Rutherford, S., The Green Infrastructure Guide: Issues, Implementation Strategies and Success Stories, West Coast Environmental Law Research Foundation British: Columbia, 2007.

[31] Low, T. E. (2011). Treatment Train, http:/groups.google.com/group/ rainwaterincontext/browse_thread/thread/1c02b65c80c9d0ea?hl=en

[32] Broughton, J. (2012). Stormwater Treatment Train, http://www.stormh2o.com 